\title{
Adhesion to and Viability of Listeria monocytogenes on Food Contact Surfaces
}

\author{
SÓNIA SILVA,* PILAR TEIXEIRA, ROSÁRIO OLIVEIRA, AND JOANA AZEREDO
}

Institute for Biotechnology and Bioengineering, Centre of Biological Engineering, University of Minho, 4710-057 Braga, Portugal

MS 07-408: Received 1 August 2007/Accepted 12 December 2007

\begin{abstract}
Listeria monocytogenes is an important pathogen responsible for major outbreaks associated with food products. Adhesion to surfaces leads to significant modifications in cell physiology. The aim of this work was to determine the adhesion ability of 10 isolates of L. monocytogenes to eight materials commonly used in kitchens and to evaluate the viability of the adhered cells. The materials assayed were stainless steel 304, marble, granite, glass, polypropylene from a bowl and from a cutting board, and two kinds of silestone. All L. monocytogenes strains attached to all surfaces, although to different extents. $L$. monocytogenes adhered most tightly to granite and marble, followed by stainless steel 304, glass, silestones, and finally polypropylene surfaces. Surfaces at the threshold between hydrophobicity and hydrophilicity, with high electron acceptor capability and a regular pattern of roughness, were more prone to attachment. Polypropylene surfaces displayed the highest percentage of viable bacteria (nearly 100\%), whereas marble and granite had a lower percentage of cultivable cells, 69.5 and $78.7 \%$, respectively. The lowest percentage of culturable bacteria was found on white silestone (18.5\%). These results indicate that there are differences in adhered cell viability on different materials. Cell viability assays are important to better understand the cross-contamination process because only adhered bacteria that remain viable are responsible for postprocess contamination.
\end{abstract}

Contaminated surfaces can transmit pathogens to food in industrial and domestic food handling environments. Exposure to pathogens on surfaces may take place either directly by contact with contaminated objects or indirectly via aerosols originating from the surface (38). Various bacteria of public health significance, including Escherichia coli, Salmonella, and Listeria monocytogenes, can survive on hands, sponges, clothes, utensils, and currency for hours or days (20, 23, 35). Pathogenic bacteria may remain on equipment surfaces even after disinfection procedures are applied, increasing the risks associated with the transmission of diseases $(2,14)$. Therefore, domestic and industrial food handling environments can be important sources of foodborne pathogens.

L. monocytogenes has been responsible for major outbreaks associated with dairy and other food products (15). This organism is frequently isolated from food-processing and natural environments $(18,21,29)$. L. monocytogenes is found in many types of food products (12), especially raw and ready-to-eat products such as milk, meat, cheese, and flour (28). Raw foods provide a source of the pathogen from which it may be spread to food contact surfaces (5). Postprocess contamination of a food product with L. monocytogenes is an ongoing problem (15) because the pathogen can survive and grow at refrigeration temperatures (as low as $-1.5^{\circ} \mathrm{C}$ ) and in environments with reduced water activity. This bacterium tolerates freezing and high salt concentrations (up to 30\%) and grows at $\mathrm{pH}$ values below 5.0 (4). The capacity of L. monocytogenes to attach to common food contact surfaces such as plastic, rubber, stainless steel,

\footnotetext{
* Author for correspondence. Tel: +351 253604419; Fax: +351 253678986; E-mail: soniasilva@deb.uminho.pt.
}

and glass has been documented $(10,17,26,36,39)$. However, differences have been reported in both the extent and rate of adsorption, depending on the surface (37). The factors governing the adhesion of bacteria to surfaces are still not well understood. In several studies, the adhesion of bacteria partly depended on both the nature of the inert surfaces and the properties of the bacterial surface $(8,11,16$, $42,45)$. Nevertheless, in some situation it has been difficult to establish a relationship between surface properties and the extent of bacterial adhesion $(10,30,31,33)$. Adhesion and colonization of surfaces lead to important modifications in cell physiology, which can influence the viability of the microorganisms $(3,22,48,49)$. However, few studies have focused on the effect of adhesion on viability of L. monocytogenes adhered to different materials $(22,49)$.

The aim of this work was to determine the adhesion ability of 10 isolates of L. monocytogenes to eight materials commonly used in kitchens and to evaluate the viability of the adhered cells.

\section{MATERIALS AND METHODS}

Bacterial cells and culture conditions. Ten L. monocytogenes strains were used in this study (sources and serotypes listed in Table 1). For each experiment, the strains were subcultured on Trypticase soy agar (TSA; Merck, Darmstadt, Germany) for $48 \mathrm{~h}$ at $37^{\circ} \mathrm{C}$ and then grown in $25 \mathrm{ml}$ of Trypticase soy broth (TSB; Merck) at $25^{\circ} \mathrm{C}$ for $24 \mathrm{~h}$. After this period, $100 \mu \mathrm{l}$ of each culture was transferred to $100 \mathrm{ml}$ of fresh TSB and incubated overnight at $25^{\circ} \mathrm{C}$. Overnight cultures were washed by centrifugation at $4,000 \times g$ at $4^{\circ} \mathrm{C}$ for $15 \mathrm{~min}$ (3-16K, Sigma Laborzentrifugen $\mathrm{GmbH}$, Osterode, Germany) twice in phosphate-buffered saline (PBS; $0.1 \mathrm{M}, \mathrm{pH} 7$ ) and once in mineral water (Fastio, Gerês, Portugal) and resuspended in the same water to a concentration 
TABLE 1. Strains, sources, and serotypes of L. monocytogenes used in this study

\begin{tabular}{rll}
\hline Strain & \multicolumn{1}{c}{ Source } & Serotype \\
\hline 1562 & Clinical & $4 \mathrm{~b}$ \\
994 & Food & $4 \mathrm{ab}$ \\
930 & Food & $1 / 2 \mathrm{~b}$ \\
925 & Food & $1 / 2 \mathrm{~b}$ \\
747 & Food & $1 / 2 \mathrm{~b}$ \\
923 & Environmental & $4 \mathrm{~b}$ \\
832 & Environmental & $1 / 2 \mathrm{~b}$ \\
812 & Environmental & $1 / 2 \mathrm{~b}$ \\
924 & Environmental & $1 / 2 \mathrm{~b}$ \\
1559 & Environmental & $1 / 2 \mathrm{~b}$ \\
\hline
\end{tabular}

of $1 \times 10^{8}$ cells per $\mathrm{ml}\left(\mathrm{OD} 600_{\mathrm{nm}}=0.3\right)$. These suspensions were used in subsequent assays.

Materials. The materials assayed were marble (Sivec from Greece), granite "Pedras Salgadas" (Vila Pouca de Aguiar, Portugal), stainless steel (SS) 304, glass, polypropylene from a kitchen bowl $(\mathrm{PPb})$, polypropylene from a cutting board (PPcb), and two kinds of silestone, white (wST) and beige (bST) (Cosentino, Macael, Spain). Silestone is a synthetic material composed of $94 \%$ quartz with an antibacterial agent incorporated (Triclosan). The materials were cut in squares of 2.0 by $2.0 \mathrm{~cm}^{2}$ and cleaned by immersion in a $0.2 \%$ solution of a commercial detergent (Sonazol Pril, Alverca, Portugal) followed by immersion in ethanol. Each individual square was well rinsed with ultrapure water and dried at $60^{\circ} \mathrm{C}$.

Bacteria and materials hydrophobicity. Hydrophobicity was evaluated through contact angle measurements and using the approach of van Oss and coworkers $(44,45)$. The degree of hydrophobicity of a given material was expressed as the free energy of interaction (i) between two entities of that material when immersed in water (w): $\Delta G_{\text {iwi }}$. If the interaction between the two entities is stronger than the interaction of each entity with water $\left(\Delta G_{\text {iwi }}<0\right)$, the material is considered hydrophobic; if $\Delta G_{\text {iwi }}>$ 0 , the material is hydrophilic. $\Delta G_{\text {iwi }}$ can be calculated through the surface tension components of the interacting entities. Contact angle measurements (at least 25 determinations for each liquid and for each material and microorganism) were done by the sessile drop technique on the cell lawns and on the materials with a contact angle measurement apparatus (OCA 15 PLUS, Data-Basics, Inc., Cleveland, Ohio). All the measurements were performed at room temperature. For bacteria, the measurements were made from bacterial layers deposited on membrane filters, according to a method described by Busscher et al. (7). Contact angles were determined using the reference liquids ultrapure water, $\alpha$-bromonaphthalene, and formamide, whose surface tension components were obtained from the literature (19).

Surface roughness. Material surface roughness and topography was assessed by atomic force microscopy, using a PicoPlus scanning probe microscope (Molecular Imaging, Agilent, Santa Clara, Calif.). Surface images were obtained in Tapping mode. The samples were analyzed in air at room temperature. Hard surface topography (granite, marble, glass, SS 304, and the two kinds of silestone) was obtained using an Si tip with a spring constant of approximately $42 \mathrm{~N} / \mathrm{m}$; the topography of the polypropylene surfaces ( $\mathrm{PPb}$ and $\mathrm{PPcb}$ ) was imaged with an Si tip with a spring constant of approximately $2.8 \mathrm{~N} / \mathrm{m}$. The roughness measurements were performed under a scan range of 2.5 by $2.5 \mu \mathrm{m}$ using the SPIP version 4.2.2.0 software (Image Metrology A/S, Hørsholm,
Denmark). Measurements were made in three randomly chosen areas in all samples.

Adhesion assays. Squares of each test material were placed in six-well tissue culture plates (Orange Scientific, Braine-l'Alleud, Belgium) containing $5 \mathrm{ml}$ of a $1 \times 10^{8}$ cells per $\mathrm{ml}$ suspension in water. The tissue culture plates were incubated for $2 \mathrm{~h}$ at $25^{\circ} \mathrm{C}$ in a shaker rotating at $120 \mathrm{rpm}$. Negative controls were obtained by placing the coupons in water without bacterial cells. To remove unattached cells, the coupons were removed from the wells and rinsed three times by soaking for $10 \mathrm{~s}$ in distilled water. These washing steps were carefully performed to remove only the bacteria that were suspended in the liquid interface formed along the surface and to minimize cell detachment from the surface (9). The substrate squares with adhered cells were dried at $37^{\circ} \mathrm{C}$ for at least $2 \mathrm{~h}$. All experiments were done in triplicate with three repeats.

Total cell counts of adhered bacteria. Bacteria were stained by applying $100 \mu \mathrm{l}$ of a $0.01 \%$ 4',6-diamino-2-phenylindole solution (DAPI; Sigma-Aldrich, Inc., St. Louis, Mo.), directly onto the coupons for $15 \mathrm{~min}$. The materials were then rinsed in distilled water and left to air dry. Dry coupons were covered with coverslips and stored in the dark for up to 2 days. Cells were visualized under an epifluorescence microscope (Leitz, Wetzlar, Germany) coupled to a 3-CCD video camera (Axiocam HRC, Zeiss, Oberkochen, Germany) that acquires images with 820 - by 580-pixel resolution and a magnification of $\times 1,000$. With this magnification, $1 \mathrm{~cm}^{2}$ is equivalent to $1.79 \times 10^{4}$ captured images (as determined by a Neubauer chamber). For each surface analyzed, at least 20 pictures were taken covering the entire surface. The number of adhered cells per picture was determined by image analysis using automated enumeration software (Sigma Scan Pro, Systat Software, San José, Calif.). Coupons also were observed by scanning electron microscopy. The materials were immersed for $15 \mathrm{~min}$ in solutions with increasing concentrations of ethanol up to $100 \%$ (vol/vol). Before observation, the coupons were mounted on aluminum stubs with carbon tape, sputtered with gold, and observed with an S-360 scanning electron microscope (Leo, Cambridge).

Bacterial viability assays. The viability of adhered cells was assessed for each material with only one strain of L. monocytogenes. For each material, the strain selected for testing was the one for which the number of adhering cells was closest to the average obtained for all the strains assayed: 832 for SS 304 and $\mathrm{PPb}, 1,562$ for PPcb and bST, 925 for marble, 924 for granite and glass, and 923 for wST. The culturability of adhered cells was determined by enumerating the CFUs. After the adhesion assays, the coupons were immersed in $2.5 \mathrm{ml}$ of PBS in new six-well tissue culture plates. The cells were removed by scraping each coupon approximately 20 times with a sterile toothpick, and 100 $\mu l$ of the appropriate dilution was plated onto TSA. Before colony enumeration, the plates were incubated at $37^{\circ} \mathrm{C}$ for $24 \mathrm{~h}$. Total cell counts were obtained by filtering $1,000 \mu \mathrm{l}$ of the suspension containing the detached $L$. monocytogenes cells through polycarbonate membranes with a pore size of $0.2 \mu \mathrm{m}$ (Whatman, Kent, UK). After filtration, the membranes were stained with $200 \mu \mathrm{l}$ of $0.01 \%$ DAPI, and the cells were visualized under an epifluorescence microscope.

Bacterial cell membrane integrity was assessed using the LIVE/ DEAD Backlight kit (Molecular Probes, Eugene, Oreg.) (6). The two reagents (syto9 and propidium iodide) were prepared according to the manufacturer's instructions and mixed in equal proportions. The mixture (100 to $200 \mu \mathrm{l}$ per membrane) was then applied to the previously filtered cellular suspension on a polycarbonate membrane, covered with a coverslip, and incubated for $15 \mathrm{~min}$ in the dark. Cells 
TABLE 2. Contact angle, surface tension components, and free energy of interaction between two cells of the same isolate of $\mathrm{L}$. monocytogenes immersed in water $\left(\Delta \mathrm{G}_{i w i}\right)^{a}$

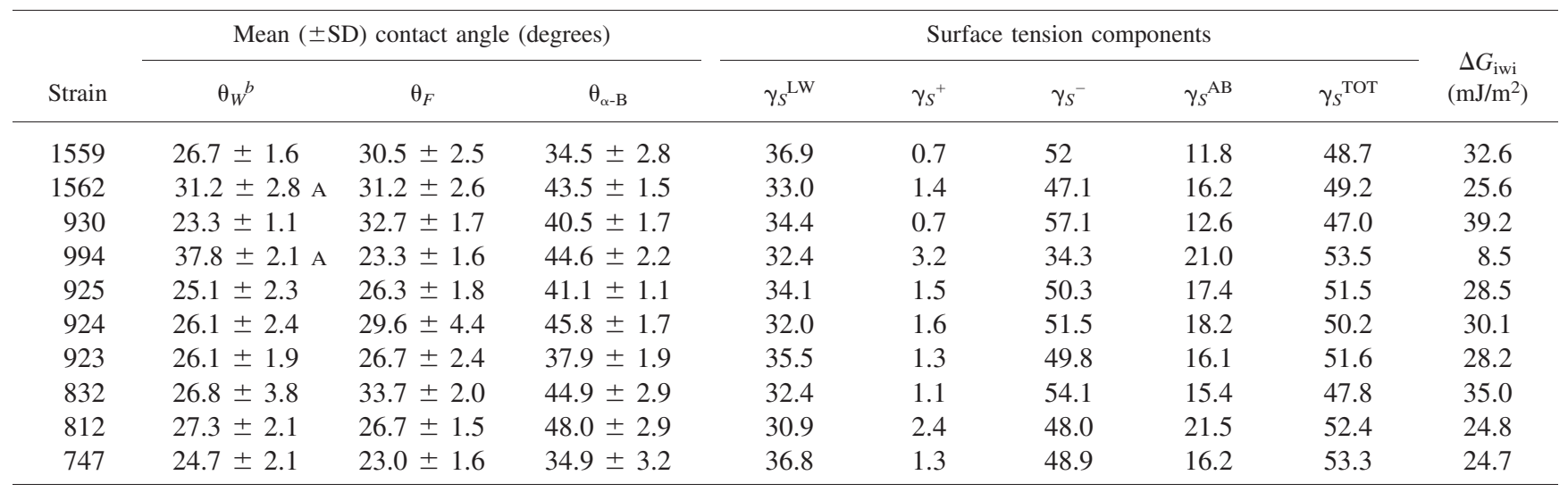

${ }^{a} \theta_{W}$, contact angle of water; $\theta_{F}$, contact angle of formamide; $\theta_{\alpha-B}$, contact angle of $\alpha$-bromonaphthalene; $\gamma_{S}{ }^{\mathrm{LW}}$, apolar Lifshtz-van der Waals surface energy component; $\gamma_{S}{ }^{+}$, electron acceptor surface energy component; $\gamma_{S}{ }^{-}$, electron donator surface free energy component; $\Delta G_{\text {iwi }}$, degree of hydrophobicity.

${ }^{b}$ Means followed by the same letter are similar $(P>0.05)$ and significantly different from those for others strains $(P<0.05)$.

were visualized under an epifluorescence microscope equipped with a filter block that simultaneously detects the two components of the mixture. For each surface analyzed, 15 pictures were taken, and the percentage of the cells with intact membranes was calculated from the mean value for each picture.

Statistical analysis. All the assays were compared using a one-way analysis of variance by applying Levene's test of homogeneity of variance and the Tukey multiple-comparison test using SPSS software (SPSS, Statistical Package for the Social Sciences, Inc., Chicago, Ill.). All tests were performed with a confidence level of $95 \%$.

\section{RESULTS}

Surface physicochemical analysis. Bacterial cell surface physicochemical characteristics are presented in Table 2. Water contact angles can be used as a qualitative indication of the cell surface hydrophobicity (32). According to Vogler (47), hydrophobic surfaces exhibit water contact values higher than $65^{\circ}$; lower values indicate hydrophilic characteristics. The values obtained for all strains assayed were quite similar, ranging from contact angles of $23.3 \pm$ $1.1^{\circ}$ (strain 930) to $27.3 \pm 2.1^{\circ}$ (strain 812). The exceptions were strains $1562\left(31.2 \pm 2.8^{\circ}\right)$ and $994\left(37.8 \pm 2.1^{\circ}\right)$, which had significantly different water contact angles $(P<$ $0.05)$. Thus, L. monocytogenes strains used in this study could be considered hydrophilic $\left(\theta_{W}<65^{\circ}\right)$. All strains were predominantly electron donors (high values of $\gamma_{S}{ }^{-}$), with low electron acceptor values $\left(\gamma_{S^{+}}\right)$(Table 2).

Substrate surface physicochemical characteristics are presented in Table 3. The highest water contact angle was displayed by $\mathrm{PPb}$, and the lowest were displayed by bST and granite. Differences in water contact angles are significant among most of the substrates $(P<0.05)$. The exceptions are SS 304 and polypropylenes, granite and bST, and marble, glass, and wST $(P>0.05)$. All the materials examined herein could be considered hydrophobic, with exception of granite and bST $\left(\theta_{W}<65^{\circ}\right)$. All those substrates have surfaces that are predominantly electron donors (high values of $\gamma_{S}{ }^{-}$). Nevertheless, granite and marble had the highest electron acceptor values $\left(\gamma_{S}^{+}\right)$(Table 3$)$.

TABLE 3. Contact angle, surface tension components, and free energy of interaction between two entities of the same material immersed in water $\left(\Delta \mathrm{G}_{i w i}\right)^{a}$

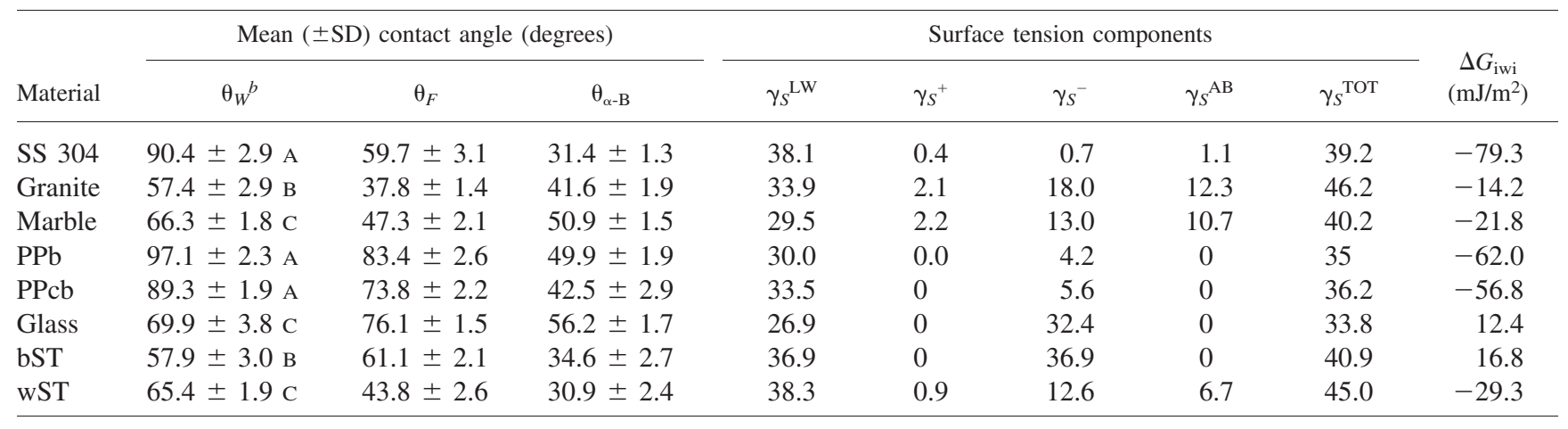

${ }^{a} \theta_{W}$, contact angle of water; $\theta_{F}$, contact angle of formamide; $\theta_{\alpha-B}$, contact angle of $\alpha$-bromonaphthalene; $\gamma_{S}{ }^{\mathrm{LW}}$, apolar Lifshtz-van der Waals surface energy component; $\gamma_{S}{ }^{+}$, electron acceptor surface energy component; $\gamma_{S^{-}}$, electron donator surface free energy component; $\Delta G_{\text {iwi }}$, degree of hydrophobicity.

${ }^{b}$ Means followed by the same letters are similar $(P>0.05)$ and significantly different from those for other materials $(P<0.05)$. 
TABLE 4. Surface roughness of materials $\left(\mathrm{R}_{\mathrm{a}}\right)$

\begin{tabular}{lc}
\hline Material & Mean $( \pm \mathrm{SD}) R_{a}(\mathrm{~nm})$ \\
\hline SS 304 & $30.9 \pm 4.4$ \\
PPb & $4.8 \pm 0.6$ \\
PPcb & $8.5 \pm 1.6$ \\
Granite & $13.1 \pm 2.3$ \\
Marble & $8.5 \pm 0.4$ \\
Glass & $1.6 \pm 0.2$ \\
WST & $31.5 \pm 1.5$ \\
bST & $24.6 \pm 6.4$ \\
\hline
\end{tabular}

According to van Oss (43), all strains of L. monocytogenes are hydrophilic (Table 2) and all materials other than granite and bST are hydrophobic (Table 3).

Surface roughness analysis. Mean surface roughness $\left(R_{a}\right)$ was obtained from roughness analysis conducted via atomic force microscopy. $R_{a}$ (in nanometers) indicates the mean distance of the roughness profile to the center plane of the profile. Substantial differences were observed among the eight surfaces assayed in this study (Table 4). The two silestones and SS 304 were the materials with the highest value of $R_{a}$, followed by granite. Both polypropylene surfaces and marble had very similar $R_{a}$ values. Glass was the material with the lowest $R_{a}$ value. The topographic images of the materials assayed obtained by atomic force microscopic examination are presented in Figure 1. Marble, granite, and $\mathrm{PPb}$ have a homogeneously distributed pattern of roughness (Fig. 1d, 1g, and 1h), and PPcb has a particular topography with some peaks but with very regular aspect (Fig. 1e). In contrast, the two silestones have a heterogeneous pattern of roughness (Fig. 1b and 1c). SS 304 is regularly marked by grooves and crevices (Fig. 1a), probably because of structural grains.

Adhesion assays. The results of the adhesion assays are presented in Figures 2 and 3. All L. monocytogenes strains adhered to all materials studied. However, L. monocytogenes adhered more tightly to granite and marble, followed by SS 304 and glass. The silestones had intermediate

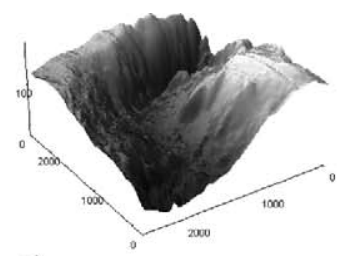

a)

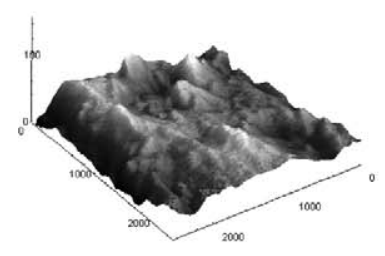

e)

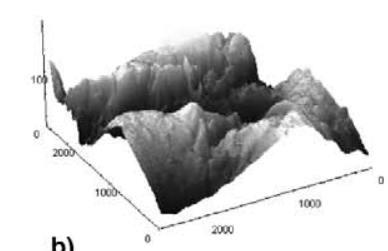

b)

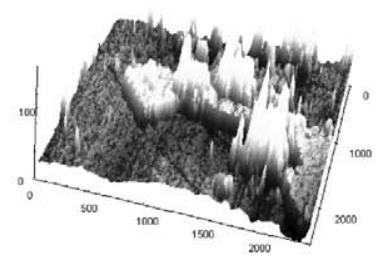

f)

adhesion, and the polypropylene surfaces (PPcb and $\mathrm{PPb}$ ) had the smallest number of adhered cells $(P<0.05)$. The number of cells adhering to marble and granite was significantly different from the number of cells adhering to the other materials $(P<0.05)$. However, between the pairs SS 304 and glass, PPb and PPcb, and wST and bST, no significant differences were found $(P>0.05)$. A large variation in the number of adhered cells was observed, ranging from $4.8 \pm 0.1 \log$ cells per $\mathrm{cm}^{2}$ (strain 994 on $\mathrm{PPb}$ ) to $6.8 \pm 0.1 \mathrm{log}$ cells per $\mathrm{cm}^{2}$ (strain 923 on marble). Strain 1559 had the highest adherence to SS 304, whereas adhesion of strains 747 and 924 to SS 304 was very low. Strains 1559 and 923 adhered in higher numbers to $\mathrm{PPb}$ than did most of the other strains $(P<0.05)$. In contrast, no significant differences in adhesion were found among the other isolates of L. monocytogenes $(P>0.05)$. All strains had similar adhesion to PPcb $(P>0.05)$. The number of attached L. monocytogenes 930 cells to granite was significantly lower than that for the other isolates. On marble, strain 923 attached at a significantly higher level than did the other strains $(P<0.05)$. L. monocytogenes 747 adhered to $\mathrm{wST}$ to a significantly higher extent than did the other strains. Concerning bST, strain 924 attached at a significantly lower level than did the others strains $(P<0.05)$. In the case of glass, strain 832 adhered to a higher extent than did most of the other strains $(P<0.05)$, whereas strain 1559 had the lowest adhesion ability $(P<0.05)$.

Bacteria viability assays. To assess any relationship between the extent of adhesion and the viability of bacteria attached to different materials, the percentage of culturable cells was determined. According to Table 5, the percentage of culturable bacteria was nearly $100 \%$ on polypropylene (PPb and PPcb) and glass. For marble, granite, and SS 304, those values were $69.7 \% \pm 12.4 \%, 78.7 \% \pm 0.8 \%$, and $89.4 \% \pm 5.0 \%$, respectively. After $2 \mathrm{~h}$ of culture on wST, only $18.4 \% \pm 3.9 \%$ of L. monocytogenes cells remained culturable, whereas for bST up to $74.0 \% \pm 0.4 \%$ culturable cells were found. To complement and confirm the results obtained as CFU counts, membrane integrity of adhered $L$.

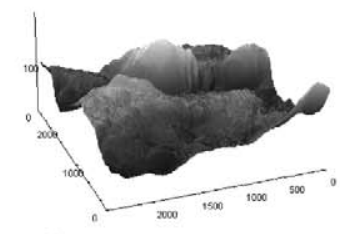

c)

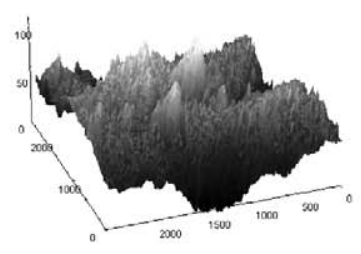

g)

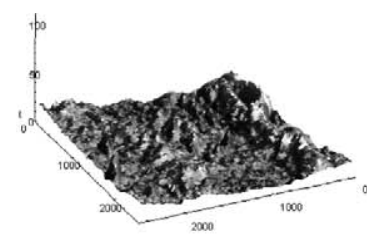

d)

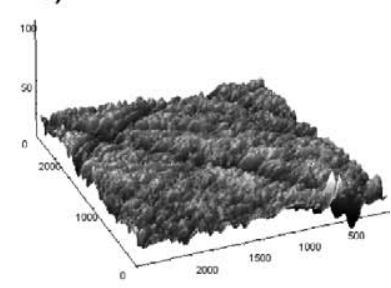

h)

FIGURE 1. Atomic force microscopy three-dimensional images (surface topography): (a) stainless steel (SS 304), (b) white Silestone (wST), (c) beige Silestone (bST), (d) polypropylene from a bowl (PPb), (e) polypropylene from a cutting board (PPcb), $(f)$ glass, $(g)$ granite, and (h) marble. 


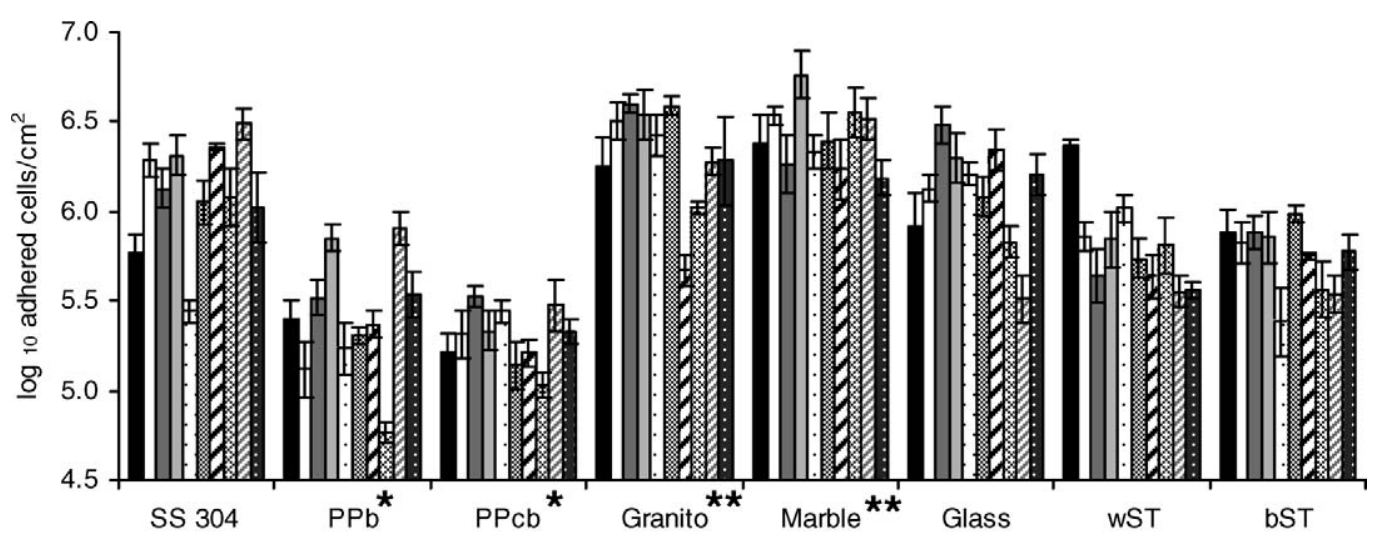

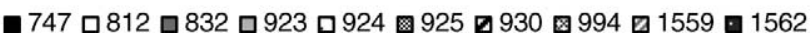

FIGURE 2. For different strains of L. monocytogenes, log number of cells per square centimeter adhered to stainless steel (SS 304), polypropylene from a bowl (PPb), polypropylene from a cutting board (PPcb), granite, marble, glass, white Silestone (wST), and beige Silestone $(b S T)$. Asterisks indicate values for materials that are similar $(\mathrm{P}>0.05)$ and significantly different from values for the other materials $(\mathrm{P}<0.05)$. Error bars represent the standard deviation of three replicates.

monocytogenes cells also was evaluated by Syto9-Pi double staining (Table 5). Bacteria with intact cell membranes stain fluorescent green, whereas those with damaged membranes stain fluorescent red. The highest percentage of damaged cells were detected on wST $(20.4 \% \pm 9.4 \%$ of cells had intact membranes) followed by marble $(70.3 \% \pm 2.1 \%)$ and SS $304(78.2 \% \pm 6.2 \%)$. No bacteria with damaged cell membranes were found on either type of polypropylene. The materials with the lowest number of adhered cells had a higher percentage of viable cells.

\section{DISCUSSION}

The aim of this study was to investigate the adhesion and corresponding cell viability of 10 strains of L. monocytogenes to eight materials commonly used for kitchen surfaces. Considering the complex nature of the role of materials and bacteria surface properties in the attachment of microorganisms to abiotic surfaces, the first step in this work was to determine the surface physicochemical prop- erties of the strains and materials under study. As previously described, the water contact angles obtained for the different strains of $L$. monocytogenes were very similar, with the exception of two strains (1562 and 994) that had higher values. The water contact angles of most strains were similar to those reported by Absolom (1), $\theta_{W}=25^{\circ}$, and Mafu et al. (27), $\theta_{W}=26^{\circ}$, which confirms the reproducibility of the method. There are few references in the literature about contact angles for food contact materials. According to Vogler's criterion (47), the materials tested here are classified as hydrophobic with the exception of granite and bST, which are considered hydrophilic. These results are in accordance with previous reports, where glass has been classified as hydrophilic $(12,27)$ and polypropylene has been classified as hydrophobic (27). In contrast, SS 304 , which sometimes is classified as hydrophilic $(11,24$, 27 ), was one of the most hydrophobic materials assayed in this study. For marble, granite, and the silestones, there are no references in the literature to our knowledge.
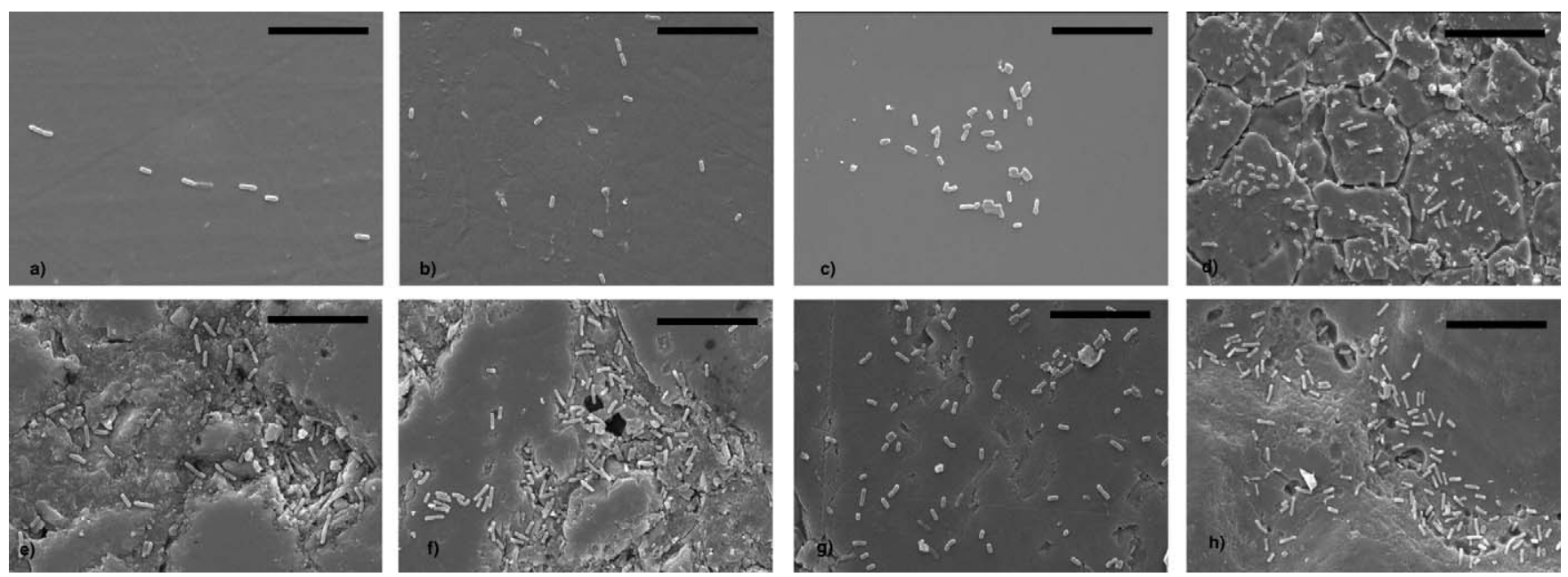

FIGURE 3. Scanning electron microscopic images of L. monocytogenes adhered to (a) polypropylene from a bowl (PPb), $(b)$ polypropylene from a cutting board (PPcb), (c) glass, (d) stainless steel (SS 304), (e) white Silestone (wST), (f) beige Silestone (bST), (g) marble, and (h) granite. Scale bars correspond to $10 \mu \mathrm{m}$. 
TABLE 5. Viability of L. monocytogenes cells after 2 h of adhesion to different materials

\begin{tabular}{|c|c|c|c|c|}
\hline Material & Strain $^{a}$ & No. of adhered cells $/ \mathrm{cm}^{2}$ & $\begin{array}{l}\text { Mean }( \pm \text { SD }) \% \\
\text { cultivable cells }\end{array}$ & $\begin{array}{l}\text { Mean }( \pm \mathrm{SD}) \% \text { cells with } \\
\text { intact membrane }\end{array}$ \\
\hline SS 304 & 832 & $1.4 \mathrm{E}+06$ & $89.4 \pm 5.0$ & $78.2 \pm 6.2$ \\
\hline $\mathrm{PPb}$ & 832 & $1.4 \mathrm{E}+05$ & $100 \pm 0.1$ & $100 \pm 0.0$ \\
\hline PPcb & 1562 & $2.1 \mathrm{E}+05$ & $100 \pm 0.0$ & $100 \pm 0.0$ \\
\hline Marble & 925 & $2.6 \mathrm{E}+06$ & $69.7 \pm 12.4$ & $70.3 \pm 2.1$ \\
\hline Granite & 924 & $2.7 \mathrm{E}+06$ & $78.7 \pm 0.8$ & $80.3 \pm 8.4$ \\
\hline wST & 923 & $7.4 \mathrm{E}+05$ & $18.4 \pm 3.9$ & $20.4 \pm 9.4$ \\
\hline bST & 1562 & $6.1 \mathrm{E}+05$ & $74.0 \pm 0.4$ & $81.6 \pm 5.6$ \\
\hline Glass & 924 & $1.6 \mathrm{E}+06$ & $98.3 \pm 2.4$ & $78.9 \pm 6.2$ \\
\hline
\end{tabular}

${ }^{a}$ Strain for which the number of adhered cells was closest to the mean for all strains.

The second part of this work was conducted to determine the ability of $L$. monocytogenes strains to adhere to the test materials. All strains adhered to all materials but to different extents depending on the material and strain. This result is similar to that obtained by other authors $(26,34)$. There was significant interstrain variability in the ability to attach to abiotic surfaces, as reported previously $(13,25$, 30). From the present results it is not possible to establish a direct correlation between the number of adhered cells and substrate surface hydrophobicity. In fact, adhesion occurred to a large extent on the material with the highest hydrophobicity (SS 304), for which results were similar to those for the moderately hydrophobic marble and the hydrophilic granite. However, the results suggest a correlation between the substrate electron acceptor parameter $\left(\gamma_{S}{ }^{+}\right)$and the number of adhered cells; marble and granite are the two materials with the highest number of adhered cells and the highest electron acceptor values.

Surface roughness also influences bacterial adhesion, and its increase has a significant effect on cell retention (40, 46). Nevertheless, no correlation was found between the number of cells adhered to the different materials and the mean surface roughness of these materials. Adhesion occurred to a greater extent to materials with the highest roughness values (SS 304 and silestones), but adhesion was similar for the smoothest material (marble). Several authors studying bacteria and yeast have reported high adhesion to surfaces with $R_{a}$ values ranging from 1.12 to $1.29 \mu \mathrm{m}(41$, 46). However, the measured roughness is in the nanometer range, and most of the tested substrates have no significant crevices or microscopic niches (of micrometer size) promoting the retention of cells. Nevertheless, scanning electron microscopic examination (Fig. 3) revealed cells attaching to microdefects on silestones and granite, indicating that small irregularities on surfaces are important because they provide entrapment sites for pioneer species. The present results suggest that $L$. monocytogenes is more prone to adhere to surfaces that are on the threshold between hydrophobicity and hydrophilicity (marble and granite), with high electron acceptor capability and a relatively regular topography, probably displaying a great number of contact points.

The present work also was conducted to assess the viability status of adhered $L$. monocytogenes cells. The results show different patterns of adhered cell viability for the dif- ferent materials studied. White silestone, marble, granite, and SS 304 are more deleterious to bacterial survival than are both types of polypropylene and glass. The results also showed that the percentage of viable cells on the surface of polypropylene and glass was close to $100 \%$, despite the lower extent of adhesion. Cells adhered to marble and granite exhibited reduced viability despite the high number of adhered cells. The lower percentage of viable cells on wST is easily explained by the presence of incorporated Triclosan in this synthetic material. In contrast, the results for bST were unexpected, because no similar cell death was observed. The stain method (LIVE/DEAD) has several advantages compared with CFU counts: it is quite easy and quick to perform, allowing rapid examination. Enumeration of bacteria by plate counting may not include all viable cells because some bacteria can lose the ability to grow on solid media even while they remain viable. A direct comparison of numbers of viable cells and culturable cells of L. monocytogenes was possible because these two approaches were applied. Because the results obtained are coincident, it is also possible that nonculturable cells also were nonviable because of damaged cell membranes.

The adhesion of L. monocytogenes to abiotic surfaces is a multifactorial phenomenon; however, at the threshold between hydrophobicity and hydrophilicity the electron acceptor capability and the pattern of roughness are determinant. This work also shows the importance of viability assays for better understanding the cross-contamination processes, because adhered bacteria that remain viable are the real culprits responsible for postprocess contamination.

\section{ACKNOWLEDGMENTS}

All strains were kindly provided by Dr. Paula Teixeira (Escola Superior de Biotecnologia, Universidade Católica Portuguesa, Porto, Portugal). The authors fully acknowledge support by Fundação para a Ciência e Tecnologia through project POCI/AGR/59358/2004.

\section{REFERENCES}

1. Absolom, D. R. 1988. Measurement of surface properties of phagocytes, bacteria and other particles. Methods Enzymol. 132:16-95.

2. Austin, J. W., and G. Bergeron. 1995. Development of bacterial biofilms in dairy processing lines. J. Dairy Res. 62:509-519.

3. Azevedo, N. F., A. P. Pacheco, C. W. Keevil, and M. J. Vieira. 2006. Adhesion of water stressed Helicobacter pylori to abiotic surfaces. J. Appl. Microbiol. 70:490-493.

4. Bacon, R. T., and J. N. Sofos. 2003. Characteristics of biological 
hazards in food, p. 157-195. In R. H. Schmidt and G. E. Rodrick (ed.), Food safety handbook. John Wiley \& Sons, Hoboken, N.J.

5. Beumer, R. R., and H. Kusumaningrum. 2003. Kitchen hygiene in daily life. Int. Biodeter. Biodegr. 51:299-302.

6. Boulos, L., M. Prevost, B. Barbeau, J. Coallier, and R. Desjardins. 1999. LIVE/DEAD (R) BacLight (TM): application of a new rapid staining method for direct enumeration of viable and total bacteria in drinking water. J. Microbiol. Methods 37:77-86.

7. Busscher, H. J., A. H. Weerkamp, H. C. van der Mei, A. W. J. van Pelt, H. P. de Jong, and J. Arends. 1984. Measurements of the surface free energy of bacterial cell surface and its relevance for adhesion. Appl. Environ. Microbiol. 48:980-983.

8. Carballo, J., C. M. Ferreirós, and M. T. Criado. 1992. Factor analysis in the evaluation of the relationship between bacterial adherence to biomaterials and change in free energy. J. Biomater. Appl. 7:130-141.

9. Cerca, N., G. B. Pier, D. R. Oliveira, and J. Azeredo. 2004. Comparative evaluation of coagulase-negative Staphylococci (CoNS) adherence to acrylic by static method and a parallel-plate flow dynamic method. Res. Microbiol. 155:755-760.

10. Chae, M. S., H. Schraft, L. T. Hansen, and R. Mackreth. 2006. Effects of physicochemical surface characteristics of Listeria monocytogenes strains on attachment to glass. Food Microbiol. 23:250-259.

11. Chamberlain, A. H. L., and S. Johal. 1988. Biofilms on meet processing surfaces, p. 75-61. In D. R. Houghton, R. N. Smith, and H. O. W. Eggins (ed.), Biodeterioration 7. Applied Science, London.

12. Cox, L. J., T. Kleiss, J. L. Cordier, C. Cordelana, P. Kondel, C. Pedrazzini, R. Beuner, and A. Siebenga. 1989. Listeria spp. in food processing, non-food and domestic environments. Food Microbiol. 6:49-61.

13. Djordjevic, D., M. Wiedmann, and L. A. McLandsborough. 2002. Microtiter plate assay for assessment of Listeria monocytogenes biofilm formation. Appl. Environ. Microbiol. 68:2950-2958.

14. Dunsmore, D. G., A. Twomey, W. G. Whitlestone, and H. W. Morgan. 1981. Design and performance of systems for cleaning product-contact surfaces of food equipment: a review. J. Food Prot. 44:220-240.

15. Farber, J. M., and P. I. Peterkin. 1991. Listeria monocytogenes, a foodborne pathogen. Microbiol. Rev. 55:476-511.

16. Hood, S. K., and E. A. Zottola. 1995. Biofilms in food processing. Food Control 6:9-18.

17. Hood, S. K., and E. A. Zottola. 1997. Adherence to stainless by foodborne microorganisms during growth in model food systems. Int. J. Food Microbiol. 37:145-153.

18. Jacquet, C., J. Rocourt, and A. Reynaud. 1993. Study of Listeria monocytogenes contamination in a dairy plant and characterization of the strains isolated. Int. J. Food Microbiol. 20:13-22.

19. Janczuk, B., E. Chibowisk, J. M. Bruque, M. L. Kerkeb, and F. J. Gonzalez-Caballero.1993. On the consistency of surface free energy components as calculated from contact angle of different liquids: an application to the cholesterol surface. J. Colloid Interface Sci. 159:421-428.

20. Jiang, X. P., and M. P. Doyle. 1999. Fate of Escherichia coli O157:H7 and Salmonella Enteritidis on currency. J. Food Prot. 62:805-807.

21. Johansson, T., L. Rantala, L. Palmu, and T. Honkanenbuzalski. 1999. Occurrence and typing of Listeria monocytogenes strains in retail vacuum-packed fish products and in a production plant. Int. J. Food Microbiol. 47:111-119.

22. Kusumaningrum, H. D., G. Riboldi, W. C. Hazeleger, and R. R. Beumer. 2003. Survival of foodborne pathogens on stainless steel surfaces and cross-contamination to foods. Int. J. Food Microbiol. 85:227-236.

23. Kusumaningrum, H. D., M. M. van Putten, F. M. Rombouts, and R. R. Beumer. 2002. Effects of antibacterial dishwashing liquid on foodborne pathogens and competitive microorganisms in kitchen sponges. J. Food Prot. 65:61-65.

24. Leclercq-Perlat, M. N., and M. Lalande. 1994. Cleanability in relation to surface chemical composition and surface finishing of some materials commonly used in food industries. J. Food Eng. 23:501-517.

25. Lunden, J. M., M. K. Miettinen, T. J. Autio, and H. J. Korkeala. 2000. Persistent Listeria monocytogenes strains show enhanced adherence to food contact surfaces after short contact times. J. Food Prot. 63:1204-1207.

26. Mafu, A. A., D. Roy, J. Goulet, and P. Magny. 1990. Attachment of
Listeria monocytogenes to stainless steel, glass, polypropylene, and rubber surfaces after short contact times. J. Food Prot. 53:742-746.

27. Mafu, A. A., D. Roy, J. Goulet, and L. Savoie. 1991. Characterization of physicochemical forces involved in adhesion of Listeria monocytogenes to surfaces. Appl. Environ. Microbiol. 57:1969-1973.

28. Mena, C., G. Almeida, L. Carneiro, P. Teixeira, T. Hogg, and P. A. Gibbs. 2004. Incidence of Listeria monocytogenes in different food products commercialized in Portugal. Food Microbiol. 21:213-216.

29. Miettinen, M. K., K. J. Bjorkroth, and H. J. Korkeala. 1999. Characterization of Listeria monocytogenes from an ice cream plant by serotyping and pulsed-field gel electrophoresis. Int. J. Food Microbiol. 46:187-192.

30. Norwood, D. E., and A. Gilmour. 2001. The differential adherence capabilities of two Listeria monocytogenes strains in monoculture and multispecies biofilm as a function of temperature. Lett. Appl. Microbiol. 33:320-324.

31. Oliveira, K., T. Oliveira, P. Teixeira, J. Azeredo, M. Henriques, and R. Oliveira. 2006. Comparison of the adhesion ability of different Salmonella Enteritidis serotypes to materials used in kitchens. $J$. Food Prot. 69:2352-2356.

32. Oliveira, R., J. Azeredo, P. Teixeira, and A. P. Fonseca. 2001. The role of hydrophobicity in bacterial adhesion, p. 11-22. In P. Gilbert, D. Allson, M. Brading, J. Verran, and J. Walker (ed.), Biofilm community interaction: change or necessity? Bioline, Cardiff, UK.

33. Oliveira, R., L. Melo, A. Oliveira, and R. Salgueiro. 1994. Polysaccharide production and biofilm formation by Pseudomonas fluorescens: effects of $\mathrm{pH}$ and surface material. Colloid Surf. 2:41-46.

34. Sasahara, K. C., and E. A. Zottola. 1993. Biofilm formation by Listeria monocytogenes utilizes a primary colonizing microorganism in flowing systems. J. Food Prot. 56:1022-1028.

35. Scott, E., and S. F. Bloomfield. 1990. The survival and transfer of microbial-contamination via cloths, hands and utensils. J. Appl. Bacteriol. 68:271-278.

36. Sinde, E., and J. Carballo. 2000. Attachment of Salmonella spp and Listeria monocytogenes to stainless steel, rubber and polytetrafluorethylene: the influence of free energy and the effect of commercial sanitizers. Food Microbiol. 17: 439-447.

37. Smoot, L. M., and M. D. Pierson. 1989. Effect of environmental stress on the ability of Listeria monocytogenes Scott A to attach to food contact surfaces. J. Food Prot. 61:1293-1298.

38. Spurlock, A. T., and E. A. Zottola. 1991. Growth and attachment of Listeria monocytogenes to cast iron. J. Food Prot. 54:925-928.

39. Stepanovic, S., I. Cirkovic, L. Rain, and M. Svabic-Vlahovic. 2004. Biofilm formation by Salmonella spp and Listeria monocytogenes on plastic surfaces. Lett. Appl. Microbiol. 38:428-432.

40. Taylor, R. L., J. Verran, G. C. Lees, and A. J. P. Ward. 1998. The influence of substratum topography on bacterial adhesion to polymethylmethacrylate. J. Mater. Sci. Mater. Med. 9:17-22.

41. Tebbs, S. E., A. Sawyer, and T. S. J. Elliott. 1994. Influence of surface-morphology on in-vitro bacterial adherence to central venous catheters. Br. J. Anaesth. 72:587-591.

42. Teixeira, P., and R. Oliveira. 1999. Influence of surface characteristics on the adhesion of Alcaligenes dentrificans to polymeric substrates. J. Adhesion Sci. Technol. 13:1287-1294.

43. van Oss, C. J. 1997. Hydrophobicity and hydrophilicity of biosurfaces. Curr. Opin. Colloid Interface Sci. 2:503-512.

44. van Oss, C. J., M. K. Chaudhury, and R. J. Good. 1987. Monopolar surfaces. Adv. Colloid Interface Sci. 28:35-64.

45. van Oss, C. J., L. Ju, M. K. Chaudhury, and R. J. Good. 1989. Estimation of the polar parameters of the surface tension of liquids by contact angle measurements on gels. J. Colloid Interface Sci. 128:313-319.

46. Verran, J., G. Lees, and A. P. Shakespeare. 1991. The effect of surface roughness on the adhesion of Candida albicans to acrylic. Biofouling 3:183-192.

47. Vogler, E. A. 1998. Structure and reactivity of water at biomaterial surfaces. Adv. Colloid Interface Sci. 74:69-117.

48. Wilks, S. A., H. T. Michels, and C. W. Keevil. 2005. The survival of Escherichia coli $\mathrm{O} 157$ on a range of metal surfaces. Int. J. Food Microbiol. 105:445-454.

49. Wilks, S. A., H. T. Michels, and C. W. Keevil. 2006. Survival of Listeria monocytogenes Scott A on metal surfaces: implications for cross-contamination. Int. J. Food Microbiol. 111:93-98. 